San Jose State University

SJSU ScholarWorks

Mineta Transportation Institute Publications

$2-2022$

\title{
Inventorying San Francisco Bay Area Parking Spaces: Technical Report Describing Objectives, Methods, and Results
}

\author{
Mikhail Chester \\ Arizona State University \\ Alysha Helmrich \\ Arizona State University \\ Rui Li \\ Arizona State University
}

Follow this and additional works at: https://scholarworks.sjsu.edu/mti_publications

Part of the Infrastructure Commons, and the Urban Studies and Planning Commons

\section{Recommended Citation \\ Mikhail Chester, Alysha Helmrich, and Rui Li. "Inventorying San Francisco Bay Area Parking Spaces: Technical Report Describing Objectives, Methods, and Results" Mineta Transportation Institute Publications (2022). https://doi.org/10.31979/mti.2022.2123}

This Report is brought to you for free and open access by SJSU ScholarWorks. It has been accepted for inclusion in Mineta Transportation Institute Publications by an authorized administrator of SJSU ScholarWorks. For more information, please contact scholarworks@sjsu.edu. 


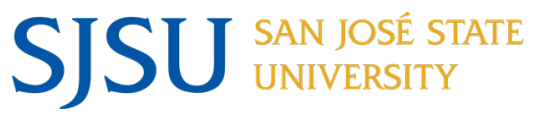

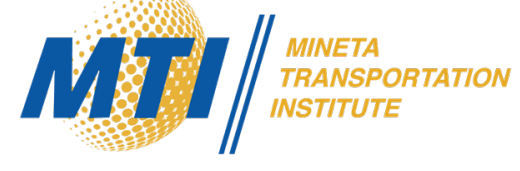

Inventorying San Francisco Bay Area Parking Spaces:

Technical Report Describing Objectives, Methods, and Results

Mikhail Chester, $\mathrm{PhD}$

Alysha Helmrich, PhD

Rui Li

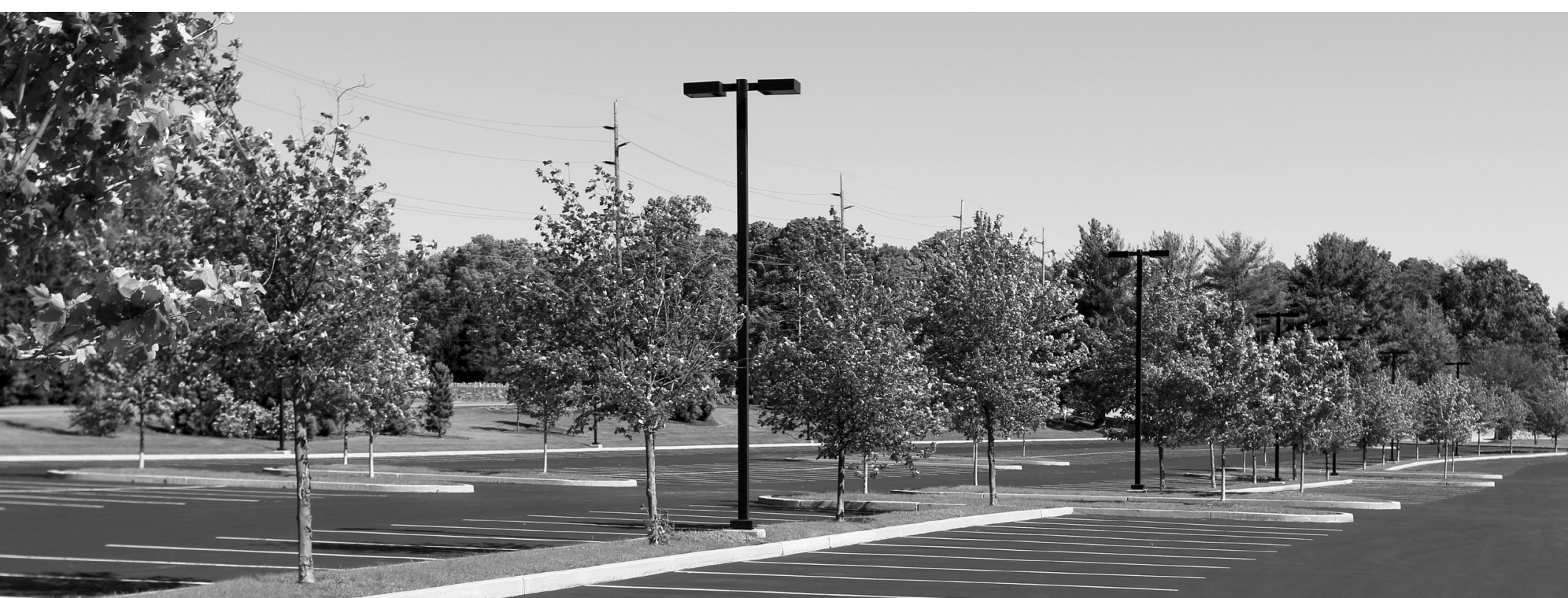

California State University
Transportation Consortium

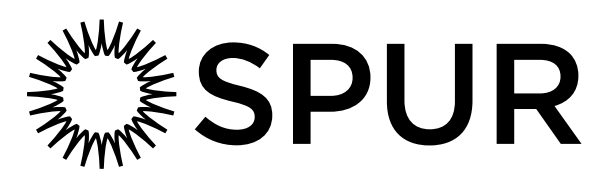




\section{MINETA TRANSPORTATION INSTITUTE}

Founded in 1991, the Mineta Transportation Institute (MTI), an organized research and training unit in partnership with the Lucas College and Graduate School of Business at San José State University (SJSU), increases mobility for all by improving the safety, efficiency, accessibility, and convenience of our nation's transportation system. Through research, education, workforce development, and technology transfer, we help create a connected world. MTI leads the Mineta Consortium for Transportation Mobility (MCTM) funded by the U.S. Department of Transportation and the California State University Transportation Consortium (CSUTC) funded by the State of California through Senate Bill I.MTI focuses on three primary responsibilities:

\section{Research}

MTI conducts multi-disciplinary research focused on surface transportation that contributes to effective decision making. Research areas include:active transportation; planning and policy; security and counterterrorism; sustainable transportation and land use; transit and passenger rail; transportation engineering; transportation finance; transportation technology; and workforce and labor. MTI research publications undergo expert peer review to ensure the quality of the research.

\section{Education and Workforce Development}

To ensure the efficient movement of people and products, we must prepare a new cohort of transportation professionals who are ready to lead a more diverse, inclusive, and equitable transportation industry. To help achieve this, MTI sponsors a suite of workforce development and education opportunities. The Institute supports educational programs offered by the Lucas Graduate School of Business: a Master of Science in Transportation Management, plus graduate certificates that include High-Speed and Intercity Rail Management and Transportation Security Management. These flexible programs offer live online classes so that working transportation professionals can pursue an advanced degree regardless of their location.

\section{Information and Technology Transfer}

MTI utilizes a diverse array of dissemination methods and media to ensure research results reach those responsible for managing change. These methods include publication, seminars, workshops, websites, social media, webinars, and other technology transfer mechanisms. Additionally, MTI promotes the availability of completed research to professional organizations and works to integrate the research findings into the graduate education program. MTI's extensive collection of transportation-related publications is integrated into San José State University's world-class Martin Luther King, Jr. Library.

\section{Disclaimer}

The contents of this report reflect the views of the authors, who are responsible for the facts and accuracy of the information presented herein. This document is disseminated in the interest of information exchange. MTl's research is funded, partially or entirely, by grants from the U.S. Department of Transportation, the U.S. Department of Homeland Security, the California Department of Transportation, and the California State University Office of the Chancellor, whom assume no liability for the contents or use thereof. This report does not constitute a standard specification, design standard, or regulation. 
REPORT 22-10

\title{
INVENTORYING SAN FRANCISCO BAY AREA PARKING SPACES: TECHNICAL REPORT DESCRIBING OBJECTIVES, METHODS, AND RESULTS
}

\author{
Mikhail Chester, $\mathrm{PhD}$ \\ Alysha Helmrich, PhD \\ Rui Li
}

February 2022 


\section{TECHNICAL REPORT DOCUMENTATION PAGE}

1. Report No. 22-10

4. Title and Subtitle

Inventorying San Francisco Bay Area Parking Spaces: Technical Report Describing Objectives, Methods, and Results

7. Authors

Mikhail Chester

Alysha Helmrich

Rui Li

9. Performing Organization Name and Address

Mineta Transportation Institute

College of Business

San José State University

San José, CA 95192-0219

12. Sponsoring Agency Name and Address

State of California SB1 2017/2018

Trustees of the California State

University

Sponsored Programs Administration

401 Golden Shore, 5th Floor

Long Beach, CA 90802
2. Government Accession No.

3. Recipient's Catalog No.

5. Report Date

February 2022

6. Performing Organization Code

8. Performing Organization Report

CA-MTI-2123

10. Work Unit No.

11. Contract or Grant No. ZSB12017-SJAUX

13. Type of Report and Period Covered Final Report

14. Sponsoring Agency Code

15. Supplemental Notes

DOI: 10.31979/mti.2022.2123 (for report)

10.31979/mti.2022.2123.ds (for dataset)

\section{Abstract}

The San Francisco Bay Area is one of the most progressive transportation regions in the deployment of high-capacity transit and use of policies to encourage active transportation. Yet like many other metro regions, there remains a dearth of knowledge on the abundance and location of parking infrastructure supply. Parking infrastructure remains one of the least catalogued infrastructure but is perhaps the most spatially dominating set of assets. The extent and location of parking supply, including on-street and off-street spaces, are estimated for the nine-county Bay Area. This parking space inventory is the most detailed assessment of parking infrastructure produced for the Bay Area, and represents an important starting point for addressing the impacts of and crafting policy for future transportation goals. Key findings from the parking census include: (1) the nine-county Bay Area has 15 million parking spaces, enough parking to wrap around the planet 2.3 times; (2) Twenty percent of the region's unincorporated land is devoted to driving and storing cars; and (3) there are approximately 2.4 spaces for every car and approximately 1.9 parking spaces for every person in the Bay Area.

\begin{tabular}{|l|l|l|l|}
\hline $\begin{array}{l}\text { 17. Key Words } \\
\begin{array}{l}\text { San Francisco, parking, inventory, } \\
\text { census, urban }\end{array}\end{array}$ & $\begin{array}{l}\text { 18. Distribution Statement } \\
\text { No restrictions. This document is available to the public through } \\
\text { The National Technical Information Service, Springfield, VA 22161 }\end{array}$ \\
\hline $\begin{array}{l}\text { 19. Security Classif. (of this report) } \\
\text { Unclassified }\end{array}$ & $\begin{array}{l}\text { 20. Security Classif. (of this page) } \\
\text { Unclassified }\end{array}$ & $\begin{array}{c}\text { 21. No. of Pages } \\
\text { 29 }\end{array}$ & 22. Price \\
\hline
\end{tabular}




\title{
Copyright $\odot 2022$ \\ by Mineta Transportation Institute \\ All rights reserved
}

DOI: 10.31979/mti.2022.2123

\author{
Mineta Transportation Institute \\ College of Business \\ San José State University \\ San José, CA 95192-0219 \\ Tel: (408) 924-7560 \\ Fax: (408) 924-7565 \\ Email: mineta-institute@sjsu.edu
}

transweb.sjsu.edu 


\section{ACKNOWLEDGMENTS}

The Mineta Transportation Institute partnered with SPUR to support the development of a census of on-and off-street parking supply for the nine-county San Francisco Bay Area. Transform and Urban Habitat served as project advisors.

This technical report, and the accompanying San Francisco Parking Census dataset, were developed by principal investigator Mikhail Chester, PhD, Alysha Helmrich, PhD, and Rui Li of the School of Sustainable Engineering and the Built Environment at Arizona State University on behalf of The Mineta Transportation Institute (MTI).

The report and accompanying dataset can be accessed from:

https://transweb.sjsu.edu/research/2123. 


\section{TABLE OF CONTENTS}

$\begin{array}{lr}\text { Executive Summary } & 1\end{array}$

$\begin{array}{ll}\text { I. Introduction } & 3\end{array}$

$\begin{array}{ll}\text { II. Methodology } & 6\end{array}$

$\begin{array}{lr}\text { Estimating On-Street Parking } & 6\end{array}$

Modeling Environment 11

III. Results 12

On-Street Parking 15

$\begin{array}{ll}\text { Off-Street Parking } & 17\end{array}$

Validation 19

$\begin{array}{ll}\text { IV. Discussion } & 21\end{array}$

$\begin{array}{lr}\text { V. Conclusion } & 24\end{array}$

$\begin{array}{lr}\text { Endnotes } & 25\end{array}$

$\begin{array}{lr}\text { References } & 26\end{array}$

$\begin{array}{lr}\text { About the Authors } & 29\end{array}$ 


\section{LIST OF FIGURES}

1. The San Francisco Bay Area 4

2. Total Parking 13

3. On-street Parking Coverage Factor by Census Block 16

4. Off-street Parking Coverage Factor by Census Block 18

5. Urban Form Types with Large Shares of Land Devoted to Parking 22 


\section{LIST OF TABLES}

1. Curb Length Reduction Factors $\quad 6$

2. Distribution of Parcels and Roads by Land Use Categories 7

3. Estimation Techniques for Edge Case Land Uses $\quad 8$

4. On-street and Off-street Parking by County and Land Use Category 14

5. Parking in Incorporated and Unincorporated Areas 15 


\section{EXECUTIVE SUMMARY}

The San Francisco Bay Area (herein, the Bay Area) is one of the most progressive transportation regions in the deployment of high-capacity transit and use of policies to encourage active transportation. Yet like many other metro regions, there remains a dearth of knowledge on the abundance and location of parking infrastructure supply. Parking infrastructure remains one of the least catalogued infrastructure but is perhaps the most spatially dominating set of assets. The extent and location of parking supply, including on-street and off-street spaces, are estimated for the nine-county Bay Area. This parking space inventory is the most detailed assessment of parking infrastructure produced for the Bay Area, and represents an important starting point for addressing the impacts of and crafting policy for future transportation goals.

On-street and off-street spaces are estimated using different approaches. On-street spaces are estimated for largely local and collector roadways based on usable curb length removing un-parkable space associated with bus stations, intersections, bridges, tunnels, driveways, and fire hydrants. Spaces on each roadway link were assigned a residential or non-residential classification. Off-street spaces were estimated by joining a regional assessor database with municipal parking requirements. The corresponding county assessor databases were from the years 2020-2021. The Metropolitan Transportation Commission's consolidated assessor database that levels the nine Bay Area counties with common land use codes was used. Parking requirements for 96 of the 101 municipalities in the Bay Area were identified (the remaining 5 were estimated as averages for other municipalities in the region). These requirements were largely from contemporary years, but two dated back to around 1990. The joining of the assessor databases and the requirements were largely based on bedrooms (residential) and building or parcel area (non-residential) although several exceptions (edge cases) had to be addressed. These $1 \%$ of parcels included land uses such as hospitals, schools, assembly places, universities, restaurants, stadiums, and multi-story structures. Manual counts of satellite images and supplementary data were often used to supplement or validate estimates. The results provide critical information for focusing policies and urban form changes aimed at affecting parking supply and demand towards reduced automobility.

There are an estimated 15 million spaces in the region, 8.6 million on-street and 6.4 million off-street. End-to-end, Bay Area parking would stretch around the Earth 2.3 times. There are 1.9 spaces per person, 2.7 spaces per employed individual, and 2.4 spaces per auto and light-duty truck. Residential parking dominates the share of supply at $70 \%$ and commercial at $9.4 \%$. Space density (spaces per acre) is highest in downtown San Francisco, Oakland, and San Jose largely attributed to high-rise structures. On-street parking is dominant in the North Bay, commanding $78 \%$ of total parking in Napa, $75 \%$ in Solano, $68 \%$ in Sonoma, and $67 \%$ in Marin County. Pockets of dense off-street parking are seen throughout the Bay Area but tend to be concentrated in the more heavily urbanized areas along the East Bay and Peninsula subregions from San Francisco and Oakland south to San Jose. There are three census blocks where the parking area exceeds land area. However, at the building scale, there are over 3,200 non-residential and 780 residential parcels where parking area exceeds land area (out of a total of 2.1 million parcels). 
Parking area constitutes $7.9 \%$ of the total incorporated area. By comparison, less than $1 \%$ of the region's incorporated area can be characterized as dense, mixed-use areas that support walking and transit. ${ }^{1}$ Certain zoning practices can drive the share of parking up significantly. Commercial neighborhoods dominated by low-rise buildings with large surface lots have parking land area shares of $21-44 \%$ of total land area, and stadiums with extensive surface lots can command $81 \%$ of land area for parking.

Comparing the Bay Area against Los Angeles and Phoenix provides helpful insights into the commitment, extent, and utilization of parking. The Bay Area with a population of 7.7 million people has less parking per person (1.9 spaces) than the Phoenix metro region (4.0 million people and 2.7 spaces per person) but the same as Los Angeles County (9.8 million people and 1.9 spaces per person). The Bay Area has 2.4 spaces per auto and light-duty truck, well below Phoenix metro (4.3) and Los Angeles County (3.3). It also outperforms on spaces per job at 2.7 (with Phoenix metro at 6.6 and Los Angeles County at 4.7). The portion of paved surfaces taken up by parking in the Bay Area is significantly smaller than Phoenix Metro and Los Angeles County. Approximately $20 \%$ of the incorporated area of the Bay Area is paved with parking $(7.9 \%)$ and roadways $(12.4 \%)$. This is roughly one-half that of the $36 \%$ paved Phoenix metro (10\% parking, $26 \%$ roadways) and the $41 \%$ paved Los Angeles County (14\% parking, $27 \%$ roadways). 


\section{INTRODUCTION}

Parking appears to persist as one of the largest yet largely unaccounted infrastructure in urban areas. Parking seems to be everywhere, and with growing evidence of the consequences of abundant and underpriced parking, regions generally have little to no information about the extent of the infrastructure, critical information necessary to focus policymaking, such as pricing strategies and zoning decisions. As such, creating parking infrastructure estimates that are spatially resolute represents an important frontier for urban policymakers and researchers, and makes an important contribution to those who are seeking to shift driving behavior to more sustainable modes.

Few studies have attempted to systematically estimate parking inventories across an entire urban area or region. Existing estimates tend to follow one of three primary approaches: 1) analyzing satellite imagery (Akbari et al., 2003); 2) surveying (Davis et al., 2010); 3) applying gross space-to-vehicle ratios (Chester et al., 2010), and 4) applying parking requirements to land use (assessor) databases (Chester et al., 2015; Hoehne et al., 2019). The analysis of satellite imagery is promising but distinguishing between parking and other surfaces and developing meaningful parking space counts is challenging. Some cities have produced parking space counts when enacting parking policy. These efforts are usually focused on smaller areas such as central business districts where particular policy or technologies will be deployed. The application of gross space-to-vehicle ratios can provide a big-picture perspective of parking but is not spatially explicit, and its accuracy requires validation. Chester et al. (2010) used this approach to develop bounding scenarios of parking space totals for the U.S., estimating between 730 to 840 million spaces, and the corresponding energy and emissions footprint relative to vehicle travel. The application of parking requirements to assessor databases yields region-wide estimates but requires extensive data analytics and must address historical changes in parking requirements. The result, however, is spatiallyexplicit estimates of parking associated with parcels or neighborhoods, and associated with land uses. For regions that are focused on developing broad parking policies or are concerned about the spatial impacts of parking, the third approach yields rich and targeted information. For example, a parking space inventory for Los Angeles County was used to analyze car-sharing behavior (Brown, 2019; Chester et al., 2015), and an inventory for the Phoenix Metro Area shows where the infrastructure contributes to heat island (Hoehne et al., 2019, 2020). Where significant changes to parking policy are being considered, detailed estimates of parking inventories are needed. This is the case of the San Francisco Bay Area (herein, the Bay Area), a region with a history of progressive transportation policies aimed at achieving environmental and equity goals that has recently been exploring alternative policies for existing parking standards. 


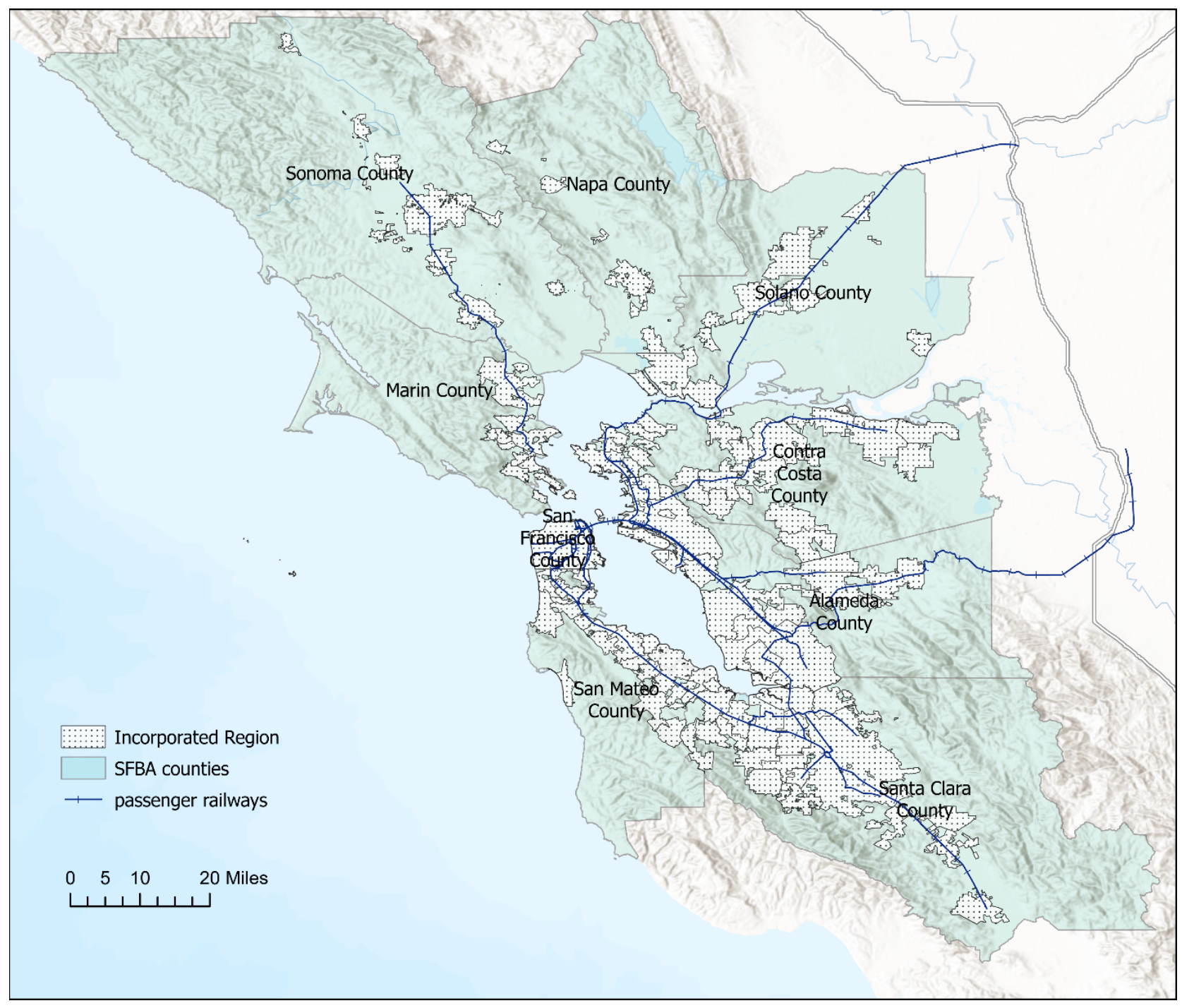

Figure 1. The San Francisco Bay Area. San Francisco Bay Area's nine counties, incorporated regions and major passenger railways are shown.

Source: Original work of the authors for this report.

The Bay Area in Northern California, with a population of approximately 7.2 million, is the second largest urban area in California and the seat of the fifth largest combined statistical area in the U.S. (Census Bureau, 2010, 2021). With a land area of 938,229 acres, the incorporated region is constrained by the Pacific Ocean, San Francisco Bay, and mountains (Metropolitan Transportation Commission, 2019). Aggressive conservation efforts have protected open space (e.g., micro parks to nature preserves) accounting for over one-quarter of the region's total land area (Grant \& Szambelan, 2019; McGhee et al., 2014). These geographic realities in part help explain a history of progressive transportation policies. The region deployed local and long-distance rail systems that have affected growth (Cervero, 1993), tested alternative fuel vehicle and fuel technologies (Chandler, 2008), piloted novel models for carsharing (Beroldo, 1990; Shaheen et al., 2016), and aggressively pursued the promotion of walking, biking, and transit (Nolan \& Reiskin, 2016). In 2010 the City of San Francisco piloted a dynamic parking pricing program in the central business district, aimed at 
deploying novel technologies to help manage supply and demand (Fabusuyi \& Hampshire, 2018). There has been growing interest in the region to rethink parking supply more broadly (Angst, 2021; SF Gate, 2018).

Towards advancing insights into the extent and characteristics of parking in the Bay Area, we have developed a parking space inventory for the region. The space inventory includes on-street and off-street parking, and its associated land uses. We start by describing our approach, the use of assessor databases and city-specific parking requirements to estimate parking spaces at parcels and aggregated to census blocks. We then discuss our results detailing on-street and off-street space characteristics. We conclude by discussing some implications for the parking inventory. The parking space inventory is the most detailed assessment of parking infrastructure produced for the Bay Area and represents an important starting point for addressing the impacts of surplus parking and crafting policy for future transportation goals. 


\section{METHODOLOGY}

The approach consists of two phases. In the first phase, on-street parking spaces are estimated by evaluating curb length and removing 'unparkable' segments. In the second phase, off-street spaces are estimated by joining a Bay Area assessor database with cityspecific parking requirements.

\section{ESTIMATING ON-STREET PARKING}

On-street parking was estimated from curb lengths of residential and secondary roadways. OpenStreetMap (OSM) provides 36 types of roadway classifications including highway, busway, bike and pedestrian path, and trunk road. Residential, secondary, and tertiary roadways with a travel speed less than $45 \mathrm{mph}$ (amounting to 22,029 road-miles) were selected as these correspond largely to local and collector roadways, where on-street parking is most likely to exist and be utilized. Further, on-street parking in unincorporated areas (amounting to 9,421 road-miles) is likely rarely used as it is largely rural roads. Therefore, on-street parking in unincorporated regions was removed. Roadways were additionally classified as either residential or non-residential based on roadway type tag in OSM. Curb length was reduced to account for bus stations, intersections, bridges, tunnels, driveways, and fire hydrants, as per Table 1. A curb space length is needed to assess the number of on-street spaces and area. For all counties excluding San Francisco, an average curb space length of $20 \mathrm{ft}$ and width of $7.5 \mathrm{ft}$ was used (area of $150 \mathrm{sq}-\mathrm{ft}$ ). In San Francisco County/City, there are 50 road-miles of perpendicular on-street parking (Moran, 2020). This amounts to $3.7 \%$ of the 1,364 total road-miles (OpenStreetMap). The distribution of parallel and perpendicular spaces was accounted for by developing a weighted average curb space length of $18.4 \mathrm{ft}$. Metered spaces were not tagged as no region-wide dataset was identified to specify these space types. However, it is expected that metered spaces are captured in the on-street inventory.

Table 1. Curb Length Reduction Factors. On-street parking is restricted by several physical barriers. These barriers are presented along with their curb length reductions. Source: Original work of the authors for this report.

\begin{tabular}{ll}
\hline No-Parking Zone & Curb Length Reduction Estimation \\
\hline Bus Station & $33 \mathrm{ft}$ \\
Intersection & $30 \mathrm{ft}$ \\
Bridge & Asset excluded \\
Tunnel & Asset excluded \\
Driveway & $15 \mathrm{ft}$ \\
Fire Hydrant & Minus 1 parking space per $500 \mathrm{ft}$ of curb space \\
\hline
\end{tabular}

\section{Estimating Off-Street Parking}

An inventory of residential and non-residential off-street parking was developed by crossreferencing regional land parcel data with municipal off-street parking requirements. 
Parcels are flagged based on land use codes that include major categories such as residential, commercial retail, commercial office, recreational, industrial, agricultural, institutional, and miscellaneous. Commercial retail included uses such as retail stores, shopping centers, restaurants, gas stations; commercial office accounts for land uses such as office buildings, medical buildings, financial buildings, skyscrapers. 211 land use codes were used to describe off-street parking requirements for 98 municipalities across 9 counties in the Bay Area. Each county used a unique subset of land use codes to identify their parcels: Alameda (81 of the 211 codes are used), Contra Costa (63), Marin (22), Napa (39), San Francisco (54), San Mateo (88), Santa Clara (104), Solano (51), and Sonoma (145). Marin county, for instance, primarily used general land use code for major land uses (e.g., 'Commercial (General)' was used for all commercial retail uses). Meanwhile, other counties used further delineations of land use types within the major categories presented.

Each county in the Bay Area maintains a separate assessor database that describes for each parcel, the land use code and other characteristics (e.g., building area, parcel area, number of bedrooms, etc.). A parcel "encloses a contiguous area of land for which location and boundaries are known, described, and maintained, and for which there is a history of defined, legally recognized interests" (National Research Council, 2007). A key challenge was working across the 9 assessor databases that each used a separate set of land use codes. A consolidated assessor database was provided by the Bay Area's Metropolitan Transportation Commission (MTC), including a consistent set of land use codes applicable for all 9 counties. All counties had complete parcel data reported and were published between March 2019 and January 2020. An overview of the distribution of parcels by land use category and county is shown in Table 2.

Table 2. Distribution of Parcels and Roads by Land Use Categories. On-street percentages describe the fraction of roadways classified as residential versus non-residential. Off-street percentages were calculated as the proportion of total parcels. Source: Original work of the authors for this report.

\begin{tabular}{|c|c|c|c|c|c|c|c|c|c|c|}
\hline \multirow[b]{2}{*}{ County } & \multicolumn{8}{|c|}{ Off-street Land Use Category } & \multicolumn{2}{|c|}{ On-street Road Category } \\
\hline & Residential & $\begin{array}{c}\text { Commercial } \\
\text { Retail }\end{array}$ & $\begin{array}{l}\text { Commercial } \\
\text { Office }\end{array}$ & Public Service & Recreational & Industrial & Agricultural & Miscellaneous & Residential & $\begin{array}{c}\text { Non- } \\
\text { residential }\end{array}$ \\
\hline Alameda & $93 \%$ & $2 \%$ & $1 \%$ & $2 \%$ & $0 \%$ & $1 \%$ & $2 \%$ & $0 \%$ & $67.16 \%$ & $32.84 \%$ \\
\hline Contra Costa & $96 \%$ & $1 \%$ & $0 \%$ & $1 \%$ & $0 \%$ & $0 \%$ & $1 \%$ & $0 \%$ & $72.19 \%$ & $27.81 \%$ \\
\hline Marin & $92 \%$ & $1 \%$ & $2 \%$ & $2 \%$ & $0 \%$ & $1 \%$ & $2 \%$ & $0 \%$ & $71.70 \%$ & $28.30 \%$ \\
\hline Napa & $89 \%$ & $3 \%$ & $0 \%$ & $0 \%$ & $0 \%$ & $1 \%$ & $6 \%$ & $0 \%$ & $63.85 \%$ & $36.15 \%$ \\
\hline San Francisco & $93 \%$ & $2 \%$ & $1 \%$ & $1 \%$ & $0 \%$ & $1 \%$ & $2 \%$ & $1 \%$ & $70.84 \%$ & $29.16 \%$ \\
\hline San Mateo & $94 \%$ & $2 \%$ & $1 \%$ & $0 \%$ & $0 \%$ & $1 \%$ & $1 \%$ & $0 \%$ & $70.30 \%$ & $29.70 \%$ \\
\hline Santa Clara & $93 \%$ & $2 \%$ & $1 \%$ & $1 \%$ & $0 \%$ & $1 \%$ & $2 \%$ & $0 \%$ & $69.74 \%$ & $30.26 \%$ \\
\hline Solano & $87 \%$ & $2 \%$ & $0 \%$ & $0 \%$ & $0 \%$ & $1 \%$ & $7 \%$ & $3 \%$ & $68.71 \%$ & $31.29 \%$ \\
\hline Sonoma & $81 \%$ & $2 \%$ & $1 \%$ & $1 \%$ & $0 \%$ & $1 \%$ & $14 \%$ & $1 \%$ & $70.18 \%$ & $29.82 \%$ \\
\hline
\end{tabular}

Municipal off-street parking requirements describe the minimum number of vehicular parking spaces required for land uses. The municipal requirements were associated with one or more land use codes. These requirements vary from city to city. Of the 101 municipalities, residential and/or non-residential parking requirements were identified for 99 municipalities. Eighty-nine of the municipal codes reviewed were current as of 2020 or 2021, with the remainder varying (Belvedere: 1989; Hercules: 1998; Belmont and San Leandro: 2008; Livermore: 2010; Dixon: 2012; Windsor: 2013; Cloverdale and San 
Ramon: 2015). Atherton and Ross were the only municipalities where residential and nonresidential parking requirements were not identified. For the cities where codes were not identified, an average of the corresponding county's various municipal codes was used. This same method was used for municipalities that did not report a particular land use type. A database of Bay Area municipal codes was developed (available on GitHub at https://ruilee16.github.io/sfba parking).

The consolidated county assessor database and municipal parking requirements database were joined. Most off-street parking requirements are based on building area, lot size, or in the case of residential parcels, the number of bedrooms -- all of which are available in the consolidated assessor database. If a land use code did not have an associated parking requirement, it was assigned equivalent parking to a similar use. Some parking requirements are based on variables not found in the consolidated assessor database, and these edge cases were assessed using alternative approaches (Table 3). For instance, the number of off-street spaces required at hospitals is generally based on the number of patient beds and/or number of employees. These edge cases were handled on a case-bycase basis (Table 3). Additionally, municipalities would occasionally have different parking regulations for various zones (e.g., downtown), and these were accommodated when zoning maps were available.

Table 3. Estimation Techniques for Edge Case Land Uses. The edge cases represent instances where the land use codes were not identified in the parcel data or parking requirements did not accurately reflect reported spaces. Source: Original work of authors for this report.

\begin{tabular}{|c|c|c|}
\hline $\begin{array}{l}\text { Land Use } \\
\text { Code }\end{array}$ & $\begin{array}{l}\text { Examples of Parking Units } \\
\text { (other than building area) }\end{array}$ & Estimation Technique \\
\hline $\begin{array}{l}\text { Airports } \\
6501\end{array}$ & Specific to project & $\begin{array}{l}\text { Either Google Maps count or reported } \\
\text { by entity. }\end{array}$ \\
\hline $\begin{array}{l}\text { Assembly Places (e.g., Funeral } \\
\text { Homes, Skating Rinks, Clubs) } \\
\text { 2037, 2048, 4001, 4002, 4004, } \\
4005,4006,4007,4008,4009, \\
4012,4014,4015,4016,9215\end{array}$ & $\begin{array}{l}\text { Area of assembly area; Number of } \\
\text { seats }\end{array}$ & $\begin{array}{l}\text { Parking requirements generally } \\
\text { based on assembly and not build- } \\
\text { ing area. If parking is }>5 \text { spaces per } \\
1,000 \text { sq-ft, reduce building area by } \\
40 \% \text { and recalculate. }\end{array}$ \\
\hline $\begin{array}{l}\text { Auto Repair } \\
2024\end{array}$ & Number of bays & $\begin{array}{l}\text { Assumed } 10 \text { per facility in San Fran- } \\
\text { cisco and } 10 \text { spaces per } 1000 \text { sq-ft } \\
\text { elsewhere. }\end{array}$ \\
\hline $\begin{array}{l}\text { Car Wash } \\
2025\end{array}$ & Number of bays & Assumed 10 per facility. \\
\hline $\begin{array}{l}\text { Cemetery } \\
9108\end{array}$ & Specific to project & Assumed 10 per facility. \\
\hline $\begin{array}{l}\text { Places of Worship } \\
9101\end{array}$ & $\begin{array}{l}\text { Area of assembly/chapel area; Num- } \\
\text { ber of seats }\end{array}$ & $\begin{array}{l}\text { Parking requirements generally } \\
\text { based on assembly and not build- } \\
\text { ing area. If parking is }>5 \text { spaces per } \\
1,000 \text { sq-ft, reduce building area by } \\
50 \% \text { and recalculate. }\end{array}$ \\
\hline $\begin{array}{l}\text { Convention Centers } \\
4011\end{array}$ & $\begin{array}{l}\text { Area of assembly area; Number of } \\
\text { seats; Specific to project }\end{array}$ & $\begin{array}{l}\text { Either Google Maps count or reported } \\
\text { by entity. }\end{array}$ \\
\hline $\begin{array}{l}\text { Day Care } \\
2032\end{array}$ & $\begin{array}{l}\text { Number of students; Number of } \\
\text { employees }\end{array}$ & Assumed 10 per facility. \\
\hline
\end{tabular}




\begin{tabular}{|c|c|c|}
\hline $\begin{array}{l}\text { Land Use } \\
\text { Code }\end{array}$ & $\begin{array}{l}\text { Examples of Parking Units } \\
\text { (other than building area) }\end{array}$ & Estimation Technique \\
\hline $\begin{array}{l}\text { Gas Stations } \\
2020,2041\end{array}$ & $\begin{array}{l}\text { Number of service bays; Number of } \\
\text { employees }\end{array}$ & Assumed 5 per facility. \\
\hline $\begin{array}{l}\text { Golf Courses } \\
4028\end{array}$ & Number of tees; Number of holes & $\begin{array}{l}\text { Assumed } 4 \text { spaces per hole and } 18 \\
\text { holes. }\end{array}$ \\
\hline $\begin{array}{l}\text { Hospitals } \\
9104,9219\end{array}$ & $\begin{array}{l}\text { Number of beds; Number of employ- } \\
\text { ees }\end{array}$ & $\begin{array}{l}\text { Either Google Maps count or reported } \\
\text { by entity. }\end{array}$ \\
\hline $\begin{array}{l}\text { Marina } \\
4003\end{array}$ & Number of berths & $\begin{array}{l}\text { Assumed } 275 \text { berths per marina and } \\
1 \text { space per berth. }\end{array}$ \\
\hline $\begin{array}{l}\text { Multi-Story } \\
3003,3004,9217 \text { in Oakland } \\
\text { Downtown; } 3009 \text { in San Jose Down- } \\
\text { town;1112, 2034, 3003, } 3004 \text { in San } \\
\text { Francisco }\end{array}$ & $\begin{array}{l}\text { Parking exceptions (e.g., shared } \\
\text { parking, transit zones) }\end{array}$ & $\begin{array}{l}\text { Based on reported parking Calibrated } \\
\text { to reported parking spaces for San } \\
\text { Francisco, Oakland, and San Jose. }\end{array}$ \\
\hline $\begin{array}{l}\text { Nursing Homes } \\
9106\end{array}$ & $\begin{array}{l}\text { Number of beds; Number of employ- } \\
\text { ees }\end{array}$ & $\begin{array}{l}\text { Assumed } 100 \text { beds per nursing } \\
\text { home. }\end{array}$ \\
\hline $\begin{array}{l}\text { Restaurants } \\
2012,2013,2014,2016\end{array}$ & $\begin{array}{l}\text { Seating area; Number of seats; } \\
\text { Number of employees }\end{array}$ & $\begin{array}{l}\text { Parking requirements generally } \\
\text { based on assembly and not building } \\
\text { area. If parking is }>14 \text { spaces per } \\
1,000 \text { sq-ft, reduce building area by } \\
40 \% \text { and recalculate. }\end{array}$ \\
\hline $\begin{array}{l}\text { Schools } \\
9102,9203\end{array}$ & $\begin{array}{l}\text { Number of students; Number of } \\
\text { classrooms; Number of employ- } \\
\text { ees; Specific to project }\end{array}$ & $\begin{array}{l}\text { Assumed } 1 \text { seat per } 8 \text { sq-ft; } 1 \\
\text { parking space per } 4 \text { seats; As- } \\
\text { sume } 5 \% \text { of building area is for } \\
\text { seated area. }\end{array}$ \\
\hline $\begin{array}{l}\text { Universities } \\
9103,9204\end{array}$ & $\begin{array}{l}\text { Number of students; Number of } \\
\text { classrooms; Number of employ- } \\
\text { ees; Specific to project }\end{array}$ & $\begin{array}{l}\text { Where the university population is } \\
10,000 \text { students or greater, either } \\
\text { Google Maps count or reported } \\
\text { by entity. }\end{array}$ \\
\hline $\begin{array}{l}\text { Stadiums } \\
4010\end{array}$ & $\begin{array}{l}\text { Number of seats; Specific to } \\
\text { project }\end{array}$ & $\begin{array}{l}\text { Either Google Maps count or } \\
\text { reported by entity. }\end{array}$ \\
\hline $\begin{array}{l}\text { Theaters } \\
4020,4021\end{array}$ & $\begin{array}{l}\text { Number of seats; Number of } \\
\text { Employees }\end{array}$ & $\begin{array}{l}\text { Assumed } 1 \text { seat per } 8 \text { sq-ft; } 1 \\
\text { parking space per } 4 \text { seats; As- } \\
\text { sume } 10 \% \text { of building area is for } \\
\text { seating area. }\end{array}$ \\
\hline $\begin{array}{l}\text { Parks and Recreation } \\
4027,9202\end{array}$ & Specific to project & $\begin{array}{l}\text { Assumed on-street parking if less } \\
\text { than } 5 \text { acres (community/micro } \\
\text { parks); assumed } 30 \text { per facility if } \\
\text { greater. }\end{array}$ \\
\hline $\begin{array}{l}\text { Public Utilities } \\
9216\end{array}$ & $\begin{array}{l}\text { Number of employees; Specific } \\
\text { to project }\end{array}$ & $\begin{array}{l}\text { Assumed equivalent to office } \\
\text { use if a building is present. If no } \\
\text { building is present, } 0 \text { parking is } \\
\text { assumed. }\end{array}$ \\
\hline
\end{tabular}

The edge cases represent less than $1 \%$ of the parcel data. While the percentage is small, they can contribute significantly to the number of parking spaces in a neighborhood. For example, universities and stadiums may have a large number of spaces in a relatively small area, such as San Jose State University which operates 7,500 parking spaces (SJSU, 2021). The estimation approaches used were determined by either a) referring to parking 
codes and validating, b) estimating an average for a land use type through a manual count, or c) confirming parking at a specific location. As indicated in Table 3, counts were conducted by counting the number of spaces at a parcel location on Google Maps.

Car washes, gas stations, day cares, and golf courses were estimated per facility based on parking code requirements and cross-validated with a manual count of a sample of facilities across the region.

Spaces associated with multi-story structures were adjusted to match reported counties in downtown San Francisco, Oakland, and San Jose. Space counts of portions of the cities were available creating an opportunity for calibration. San Francisco reported 87,400 offstreet non-residential spaces in a study area marking the Northeast quadrant of the city (Schwartz et al., 2016). Oakland reported 21,235 spaces for downtown (NelsonlNygaard Consulting Associates Inc., 2016). San Jose reported 33,537 off-street spaces downtown (San Jose Downtown Association, 2021). When per square foot requirements were applied to multi-story buildings (over six stories), the estimated spaces estimated for the matching San Francisco and Oakland study areas were much larger than actual spaces reported. As such off-street multi-story reductions of $65 \%$ and $79 \%$ were applied for the respective cities in their downtown areas. In San Jose the estimates underpredicted relative to the spaces reported by $1.1 \%$. As San Francisco and Oakland have a large share of older multistory buildings reductions in parking are expected, whereas San Jose with newer buildings downtown appears to be building parking consistent with code. As such downtown off-street spaces were increased by this percentage to match. The overestimates (for San Francisco and Oakland) may correspond to facility parking variances, either because sufficient underutilized parking is nearby, alternative travel modes exist, or upon construction it was argued that not all building space would be used simultaneously. Variances differ by city, as found in their respective municipal codes (e.g., transit accessible areas reductions vary from $25 \%$ in San Francisco, 30\% in Oakland, $50 \%$ in San Jose).

Parking requirements for assembly places, places of worship, and restaurants are largely determined from assembly space, congregation areas, or seating area, respectively. Therefore, if the parking code made this specification, the building area was reduced by the listed percentage in Table $\mathbf{3}$ for multi-story parcels, which was estimated and validated through a sample of manual counts. Older places of worship in high-density areas often did not have off-street parking; therefore, if the parcel structure was built prior to 1930 -- roughly the time when off-street parking requirements emerged -- no off-street parking was assumed. This rule was also applied to pre-1930 parcels in San Francisco. A similar approach was followed for schools and theaters, but number of seats were estimated, rather than using building area. For nursing homes, an average of 100 beds per facility was assumed (Gabrel, 2000). Marina parking is based on the number of berths. There are approximately 11,000 berths across 40 marinas in the Bay Area, an average of 275 berths was assumed per marina (Boating San Francisco, 2020). Auto repair shops, cemeteries, parking lots and garages, parks and recreation spaces, and public utilities were estimated by land use type based on a manual count of select locations (at least 20 parcels) across counties utilizing the land use code. Parks under 5 acres (micro and community parks, (City of Los Angeles, 2010)), were assumed to have no off-street parking. 
For airports, hospitals, stadiums, convention centers, and universities, either the reported number of spaces was captured from facility websites, or manual counts were performed with Google Maps. Initial assessments of these facilities produced extensive parking space, so particular attention was given to developing accurate estimates.

Low-resolution assessor data for certain counties and land uses required additional alternative estimation techniques. The Marin County assessor data did not disaggregate land uses beyond a general commercial category. It was assumed that any building over one story or with a square footage greater than 3,000 was commercial office, or otherwise commercial retail. In Marin and Napa counties recreational land use codes were not used. It was assumed that tax exempt tagged parcels (often public recreation space) have 30 spaces if over 5 acres in size, consistent with the estimation technique used for parks in other counties (Table 3). Lastly, Santa Clara and San Mateo counties have agriculture parcels typically without reported building structures. For these parcels it was assumed that there are 2 spaces. There were no agricultural parcels listed for San Francisco County.

To estimate the density of off-street parking, a space size must be used. Two space sizes are considered: one for single family residential and another for multi-family residential and non-residential. For single-family residential and based on observations of off-street space sizes, a length of $20 \mathrm{ft}$ and width of $9 \mathrm{ft}$ is used, resulting in an area of $180 \mathrm{sq}-\mathrm{ft}$. For multifamily residential and non-residential off-street spaces both the space itself plus accessway is considered. An area of $330 \mathrm{sq}$. ft. is applied from (Shoup, 2014), which corresponds to a parking space plus accessways, which are typically needed for lots and structures.

\section{MODELING ENVIRONMENT}

On-street spaces were estimated using a Python program drawing from the associated data sources (e.g., OpenStreetMaps). Off-street spaces were estimated with a separate Python program, designed to join the consolidated assessor database, database of municipal offstreet parking requirements, and edge cases approaches. 


\section{RESULTS}

The parking inventory (visualized in Figure 2, quantified in Table 4) catalogues approximately 15 million parking spaces for the 7.7 million (Census Bureau, 2019) residents in the Bay Area, equating to 1.9 spaces per person. There are 2.7 spaces per every employed individual (Census Bureau, 2019). For every registered auto and lightduty truck, there are 2.4 spaces per vehicle (California DMV, 2019). There are 8.6 million on-street parking spaces (6.7 million residential and 1.9 million non-residential) and 6.4 million off-street parking spaces (3.8 million residential and 2.6 million non-residential). Assessing the distribution at a census block level, the median parking density is 19.7 total spaces per acre, 10.5 on-street spaces per acre, 8.4 off-street spaces per acre, 14.4 residential spaces per acre, and 3.5 non-residential spaces per acre.

While parking varies spatially across the Bay Area, it is concentrated in incorporated areas (Table 5). The total number of parking spaces corresponds to 68,272 acres, which is approximately $1.5 \%$ of the total 4.4 million acres of land area. However, in the 0.86 million acres of incorporated area, parking spaces are approximately $7.9 \%$ of the land area in the region. This is an average of 3.4 spaces per acre in the entire Bay Area and 13.2 spaces per acre in the incorporated region. An overview of parking by land use category and county is summarized in Table 4 . On-street parking averages $58 \%$ of total parking per county. Residential parking, the largest parking contributor, accounts for an average $71 \%$ of total parking per county. The second largest off-street parking land use is commercial (retail and office) parking, averaging $9.4 \%$ of off-street parking per county. In total the edge cases (hospitals, universities, stadiums, etc.) represent an estimated 466,829 spaces, or $7.2 \%$ of total parking spaces.

A coverage factor is used to assess the prevalence of parking spaces. A coverage factor describes the percentage of land area that is parking if all parking were surface spaces. For example, a $50 \%$ coverage factor means that if all parking in the census block were spread out it would cover one-half of the area. A coverage factor greater than $100 \%$ describes a situation where a census block has more parking area than land area. Figure 2 shows the coverage factor by census block for all spaces (on-street and off-street) across the Bay Area. 

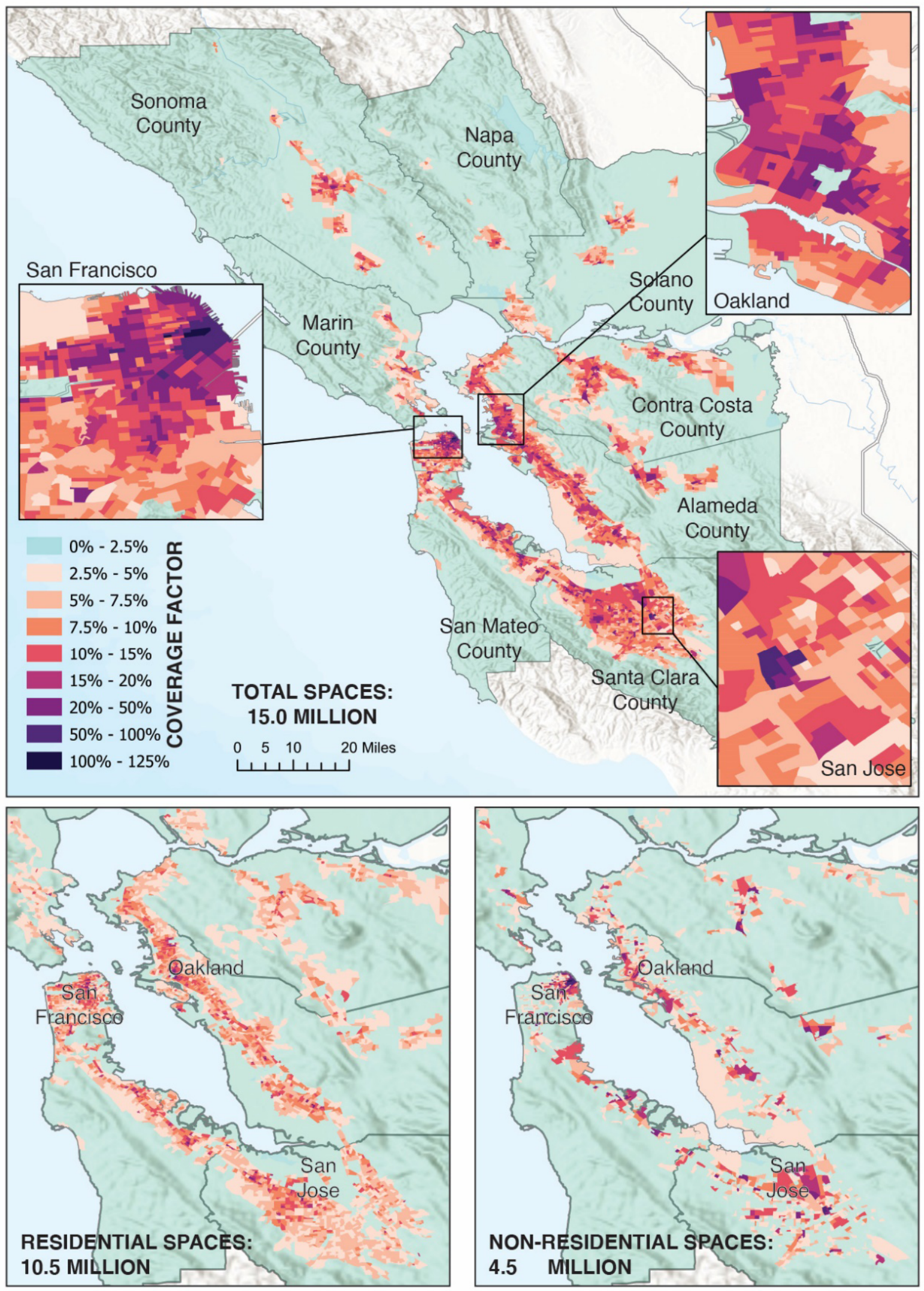

Figure 2. Total Parking (On-street and Off-street) Coverage Factor by Census Block. The coverage factor is the percentage of the census block that would be covered by parking if all parking were surface spaces. 
Table 4. On-street and Off-street Parking by County and Land Use Category. Top part of table shows parking spaces and bottom part distributions. Original work of authors for this report.

\begin{tabular}{|c|c|c|c|c|c|c|c|c|c|c|}
\hline Land Use & Alameda & $\begin{array}{c}\text { Contra } \\
\text { Costa }\end{array}$ & Marin & Napa & $\begin{array}{c}\text { San } \\
\text { Francisco }\end{array}$ & $\begin{array}{c}\text { San } \\
\text { Mateo }\end{array}$ & $\begin{array}{l}\text { Santa } \\
\text { Clara }\end{array}$ & Solano & Sonoma & SFBA Total \\
\hline \multicolumn{11}{|l|}{ Off-street Land Use Category } \\
\hline Residential & 782,019 & 684,242 & 164,506 & 80,814 & 172,845 & 395,665 & 975,860 & 248,760 & 320,712 & $3,825,423$ \\
\hline Commercial retail & 167,487 & 135,143 & 3,662 & 13,962 & 34,873 & 53,859 & 182,451 & 31,438 & 58,037 & 680,912 \\
\hline Commercial office & 113,619 & 87,505 & 67,756 & 3,006 & 71,586 & 108,839 & 237,353 & 11,103 & 35,819 & 736,586 \\
\hline Public service & 78,945 & 74,216 & 7,020 & 408 & 25,236 & 5,049 & 39,168 & 5,614 & 15,567 & 251,223 \\
\hline Recreational & 27,244 & 11,283 & 4,425 & 1,529 & 4,248 & 5,891 & 22,430 & 2,121 & 13,149 & 92,319 \\
\hline Industrial & 295,966 & 52,152 & 7,554 & 14,471 & 11,223 & 64,238 & 281,543 & 14,971 & 42,318 & 784,435 \\
\hline Agricultural & 2,477 & 251 & 76 & 51 & 0 & 421 & 7,700 & 125 & 756 & 11,856 \\
\hline Miscellaneous & 0 & 0 & 0 & 0 & 63 & 0 & 0 & 0 & 0 & 63 \\
\hline \multicolumn{11}{|l|}{ On-street Road Category } \\
\hline Incorporated Residential & 931,860 & 815,624 & 216,467 & 105,629 & 202,773 & 430,308 & 890,493 & 318,373 & 289,578 & 4,201,105 \\
\hline Unincorporated Residential & 272,437 & 297,366 & 225,394 & 252,378 & 0 & 144,324 & 237,353 & 459,970 & 635,833 & $2,525,055$ \\
\hline Total Residential Spaces & $1,986,316$ & $1,797,232$ & 606,367 & 438,820 & 375,619 & 970,297 & $2,103,706$ & $1,027,103$ & $1,246,123$ & $10,551,583$ \\
\hline Total Non-residential Spaces & $1,109,873$ & 710,318 & 156,647 & 70,725 & 258,444 & 432,412 & $1,243,677$ & 220,691 & 265,094 & $4,467,880$ \\
\hline Total of Off-street Spaces & $1,467,756$ & $1,044,791$ & 254,999 & 114,240 & 320,075 & 633,961 & $1,746,505$ & 314,132 & 486,358 & $6,382,817$ \\
\hline Total of On-street Spaces & $1,628,432$ & $1,462,758$ & 508,014 & 395,305 & 313,988 & 768,748 & $1,600,879$ & 933,662 & $1,024,859$ & $8,636,645$ \\
\hline Sum Total of Spaces & $3,096,189$ & $2,507,550$ & 763,014 & 509,545 & 634,063 & $1,402,709$ & $3,347,383$ & $1,247,794$ & $1,511,217$ & $15,019,462$ \\
\hline \multicolumn{11}{|l|}{ Off-street Land Use Category } \\
\hline Residential & $25.3 \%$ & $27.3 \%$ & $21.6 \%$ & $15.9 \%$ & $27.3 \%$ & $28.2 \%$ & $29.2 \%$ & $19.9 \%$ & $21.2 \%$ & $25.5 \%$ \\
\hline Commercial retail & $5.4 \%$ & $5.4 \%$ & $0.5 \%$ & $2.7 \%$ & $5.5 \%$ & $3.8 \%$ & $5.5 \%$ & $2.5 \%$ & $3.8 \%$ & $4.5 \%$ \\
\hline Commercial office & $3.7 \%$ & $3.5 \%$ & $8.9 \%$ & $0.6 \%$ & $11.3 \%$ & $7.8 \%$ & $7.1 \%$ & $0.9 \%$ & $2.4 \%$ & $4.9 \%$ \\
\hline Industrial & $9.6 \%$ & $2.1 \%$ & $1.0 \%$ & $2.8 \%$ & $1.8 \%$ & $4.6 \%$ & $8.4 \%$ & $1.2 \%$ & $2.8 \%$ & $5.2 \%$ \\
\hline Agricultural & $0.1 \%$ & $0.0 \%$ & $0.0 \%$ & $0.0 \%$ & $0.0 \%$ & $0.0 \%$ & $0.2 \%$ & $0.0 \%$ & $0.1 \%$ & $0.1 \%$ \\
\hline Miscellaneous & $0.0 \%$ & $0.0 \%$ & $0.0 \%$ & $0.0 \%$ & $0.0 \%$ & $0.0 \%$ & $0.0 \%$ & $0.0 \%$ & $0.0 \%$ & $0.0 \%$ \\
\hline \multicolumn{11}{|l|}{ On-street Road Category } \\
\hline Incorporated Residential & $30.1 \%$ & $32.5 \%$ & $28.4 \%$ & $20.7 \%$ & $32.0 \%$ & $30.7 \%$ & $26.6 \%$ & $25.5 \%$ & $19.2 \%$ & $28.0 \%$ \\
\hline Incorporated Non-residential & $13.7 \%$ & $14.0 \%$ & $8.7 \%$ & $7.3 \%$ & $17.5 \%$ & $13.8 \%$ & $14.1 \%$ & $12.5 \%$ & $6.6 \%$ & $12.7 \%$ \\
\hline Unincorporated Residential & $8.8 \%$ & $11.9 \%$ & $29.5 \%$ & $49.5 \%$ & $0.0 \%$ & $10.3 \%$ & $7.1 \%$ & $36.9 \%$ & $42.1 \%$ & $16.8 \%$ \\
\hline
\end{tabular}


Table 5. Parking in Incorporated and Unincorporated Areas. Parking density is higher in incorporated regions. Despite this, some counties (Napa and Sonoma) have more unincorporated parking than incorporated. Source: Original work of authors for this report.

\begin{tabular}{|c|c|c|c|c|c|c|c|c|c|c|}
\hline & Alameda & $\begin{array}{c}\text { Contra } \\
\text { Costa }\end{array}$ & Marin & Napa & $\begin{array}{c}\text { San } \\
\text { Francisco }\end{array}$ & San Mateo & $\begin{array}{l}\text { Santa } \\
\text { Clara }\end{array}$ & Solano & Sonoma & SFBA \\
\hline \multicolumn{11}{|l|}{ Parking Spaces } \\
\hline Incorporated & $2,649,409$ & $2,005,037$ & 461,165 & 204,226 & 634,063 & $1,159,058$ & $2,985,196$ & 726,341 & 702,111 & $11,526,606$ \\
\hline Uninincorporated & 446,780 & 502,513 & 301,848 & 305,319 & & 243,651 & 362,187 & 521,453 & 809,106 & $3,492,857$ \\
\hline \multicolumn{11}{|c|}{ Parking Density (Spaces per Acre) } \\
\hline Incorporated & 13.0 & 13.1 & 9.1 & 7.9 & 22.5 & 12.2 & 16.0 & 10.0 & 16.3 & 13.2 \\
\hline Uninincorporated & 0.6 & 2.6 & 0.8 & 0.5 & & 1.1 & 1.7 & 1.2 & 1.0 & 1.2 \\
\hline \multicolumn{11}{|l|}{ Parking Space Ratio } \\
\hline Incorporated & $85.6 \%$ & $80.0 \%$ & $60.4 \%$ & $40.1 \%$ & $100.0 \%$ & $82.6 \%$ & $89.2 \%$ & $58.2 \%$ & $46.5 \%$ & $76.6 \%$ \\
\hline Uninincorporated & $14.4 \%$ & $20.0 \%$ & $39.6 \%$ & $59.9 \%$ & $0.0 \%$ & $17.4 \%$ & $10.8 \%$ & $41.8 \%$ & $53.5 \%$ & $23.4 \%$ \\
\hline
\end{tabular}

\section{ON-STREET PARKING}

The 8.6 million on-street parking spaces in the Bay Area are concentrated in incorporated areas (Figure 3). The majority of on-street parking is classified as residential, averaging $78 \%$ of total on-street parking across the counties. There are 1.1 spaces per inhabitant, 1.5 spaces per employed individual, and 1.4 spaces per registered auto and light-duty truck (California DMV, 2019). San Francisco, Napa and Marin counties have less on-street parking in comparison to other Bay Area counties. Likely, on-street parking does not have the capacity to accommodate the higher density of people and jobs in San Francisco, Oakland, and San Jose. On-street parking is dominant in the North Bay counties: Napa $(78 \%$ of parking is onstreet), Solano (75\%), Sonoma (68\%), and Marin (67\%). The North Bay is less populated and incorporated than the remaining Bay Area counties. Napa and Sonoma counties, in particular, have more parking identified in unincorporated areas than incorporated areas. 

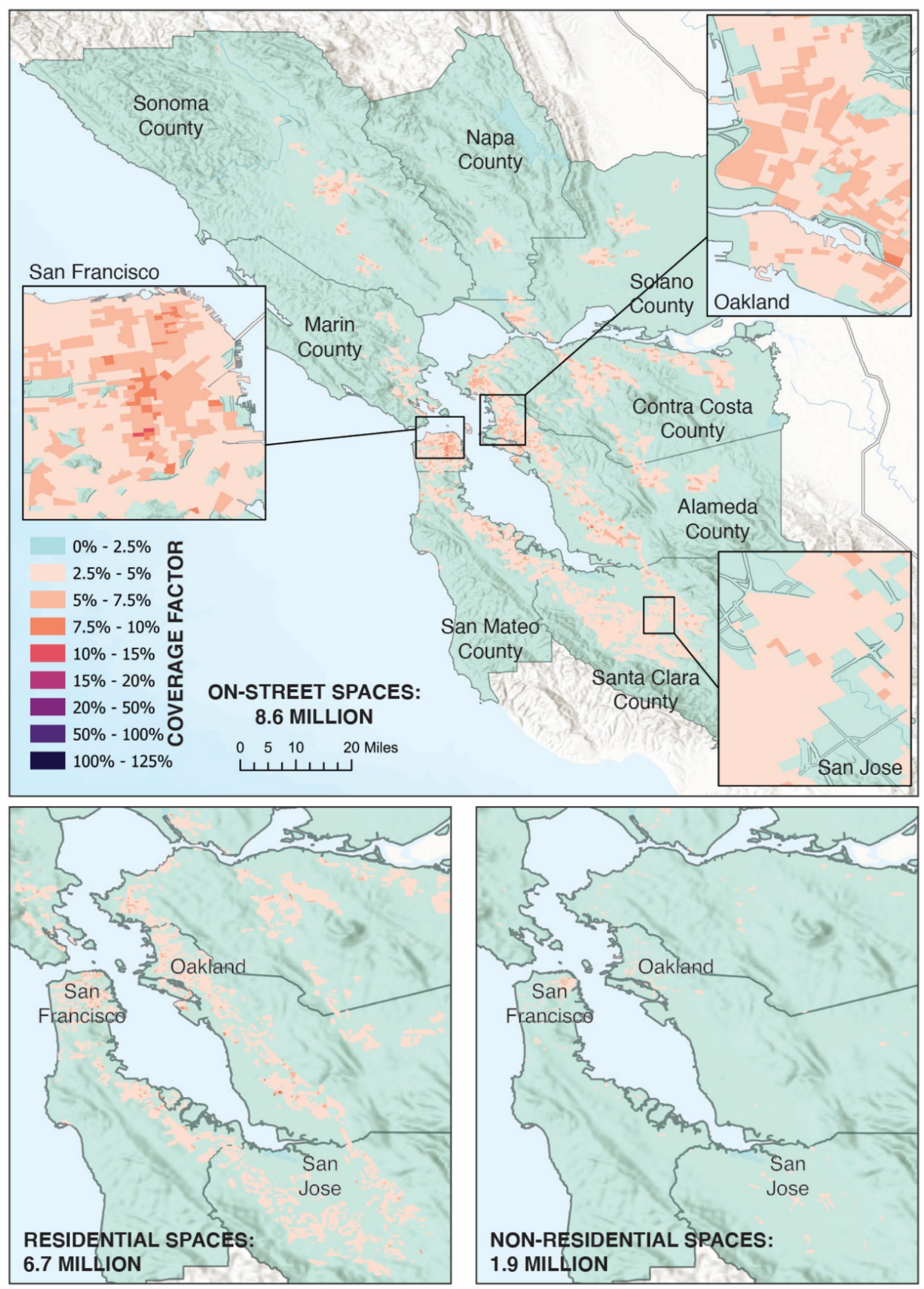

Figure 3. On-street Parking Coverage Factor by Census Block. The coverage factor is the percentage of the census block that would be covered by parking if all parking were surface spaces. 


\section{OFF-STREET PARKING}

The 6.4 million off-street spaces are concentrated in the core municipalities around the San Francisco Bay, but also are extensive in the East Bay and North Bay edge cities. The greatest densities of spaces are found in the San Francisco, Oakland, and San Jose downtown areas (Figure 4). Downtown San Francisco represents the greatest concentration of parking density owing to high-rise structures. 

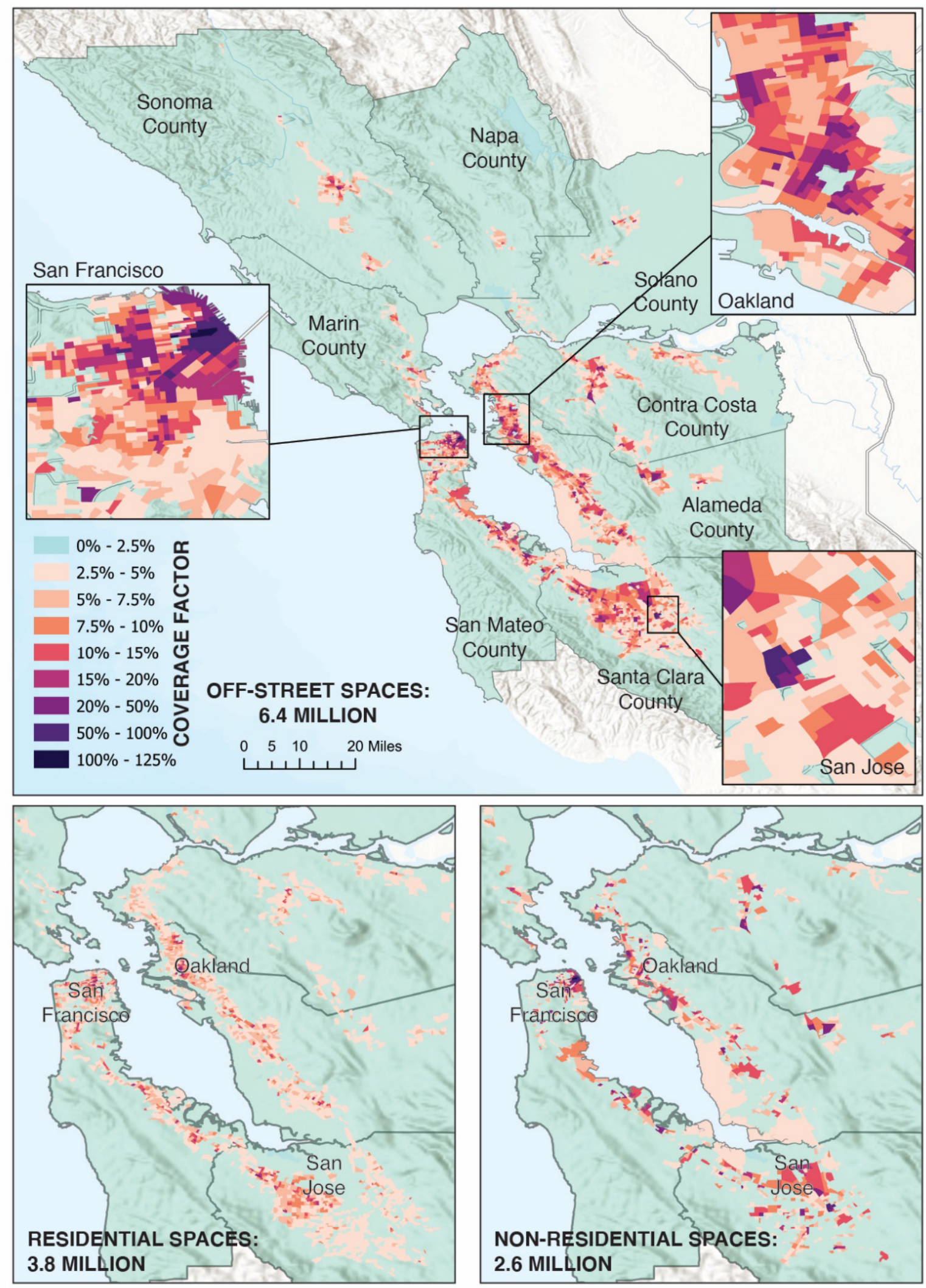

Figure 4. Off-street Parking Coverage Factor by Census Block. The coverage factor is the percentage of the census block that would be covered by parking if all parking were surface spaces. 
Off-street parking is largely associated with residential and commercial land uses, with residential accounting for $54 \%$ (Alameda County) to $79 \%$ (Solano County) of total off-street parking. This is explained by the dominating share of residential land use codes in each county (Table 2). In Alameda and Santa Clara counties industrial land uses contribute significantly to the parking inventory. In Alameda this appears to be associated with port activities and technology industry in Santa Clara.

Pockets of dense off-street parking are seen throughout the Bay Area but tend to be concentrated in the more heavily populated areas along the East Bay and Peninsula subregions from San Francisco and Oakland south to San Jose. San Francisco has the highest density of off-street parking reaching a coverage factor of $117 \%$, located in the Financial District. The median census block coverage factor for downtown San Francisco is $59 \%$, dominated by non-residential land uses. Similarly, Oakland's greatest density of spaces occurs downtown at a median coverage factor of $19 \%$, also driven by nonresidential land uses. San Jose appears unique in that it produces pockets of high-density off-street spaces (reaching a coverage factor of $84 \%$ occurring downtown) in a large area of moderate density driven by mixes of residential and non-residential land uses. Other notable pockets of high-density parking appear in the downtowns of Concord (36\% coverage factor), Walnut Creek (36\%), and Dublin (27\%).

A threshold where parking exceeds land area represents an important benchmark for understanding the spatial commitments to parking infrastructure. This threshold occurs at a coverage factor of $100 \%$. There are three census blocks (all in downtown San Francisco) where parking area exceeds land area. However, at the parcel scale, there are over 3,200 non-residential and 780 residential parcels where parking area exceeds land area (out of a total of 2.1 million parcels). This dynamic is attributed to heavy concentrations of high-rise structures where multi-story parking is prevalent, often at the base of the building or underground.

\section{VALIDATION}

Validating a region-wide parking inventory at scale is challenging as no commensurate studies of the same region exist, however, internal validation was performed on various pieces of the analysis that in aggregate increase confidence in the result's accuracy. First, over 205,000 spaces across at least 3,000 parcels were either counted manually, estimated from dedicated parking lot or structure area reporting, or confirmed via the facility's website or online parking inventories (e.g., Parkopedia, ParkMe). Significant validation efforts were made into edge cases, which were either incorrectly or vaguely labelled, not calculable with the available data, or both. Since the parking spaces could not be predicted effectively at these locations, there is no total error to present. The manual counting is subject to errors, such as out-ofdate satellite images on Google Maps, concealed parking spaces (e.g., canopy cover, solar panels), and human error. The parking inventory was developed at the parcel scale but aggregated to the census block. In general, parking error at the parcel scale was reduced when total neighborhood parking was aggregated to the census block. This is attributed to several factors, including variations at buildings from the minimum (possibly constructing more parking than the minimum at times, and less through variances at other times) and the sharing of parking across parcels (e.g., a garage may be utilized by multiple parcels). 
Validating against existing reported inventories also provides confidence in the techniques. As previously discussed for multi-story and resulting downtown areas calibration, existing parking counts exist for some regions. In addition to a downtown study area, San Francisco also reports an "extrapolated" city/county-wide estimate of 172,000 spaces (Schwartz et al., 2016). We estimate 153,000 spaces for the same region, which is grounded in a bottom-up count by facility accounting for significantly less density outside of the San Francisco study area. In San Jose our initial estimates (prior to multi-story adjustments) were within $1.5 \%$ of those reported for a downtown study area (San Jose Downtown Association, 2021).

Additionally, efforts were made to manually measure parking space sizes across on-street and off-street land uses and categories. These measurements resulted in the various parking space areas used. Furthermore, external validation is performed (see Discussion) by comparing the Bay Area results against the Phoenix metro and Los Angeles County regions, where commensurate analyses have been developed. 


\section{DISCUSSION}

The parking inventory results establish a context for assessing the efficacy of dedicating land to storing automobiles, and opportunities for guiding urban form and transportation system change. Assuming that the 6.2 million automobiles and light-duty trucks registered in the Bay Area spend 95\% of their time parked (Shoup, 2014), then at any given time on average there are 5.9 vehicles that need to be parked. With 15 million spaces, the average utilization rate is $39 \%$. This implies that there is 2.6 times as much parking available across the region than needed.

While parking is on average $7.9 \%$ of the incorporated area, there are several areas where parking can have larger impacts on the use of land. This occurs in locations where multistory buildings are less prevalent and auto-centered commercial or industrial land uses with an emphasis on surface lots are found (Figure 5). Commercial districts in downtown Livermore result in a coverage factor of $21 \%$, downtown Walnut Creek $40 \%$, and downtown Burlingame $44 \%$. The Southland Mall in Hayward commands a coverage factor of $29 \%$. Industrial areas can also be significant (e.g., industrial zones of Concord result in a coverage factor of $40 \%$ ). Sporting stadiums can be particularly egregious; the Oakland Coliseum commands an $81 \%$ coverage factor. 

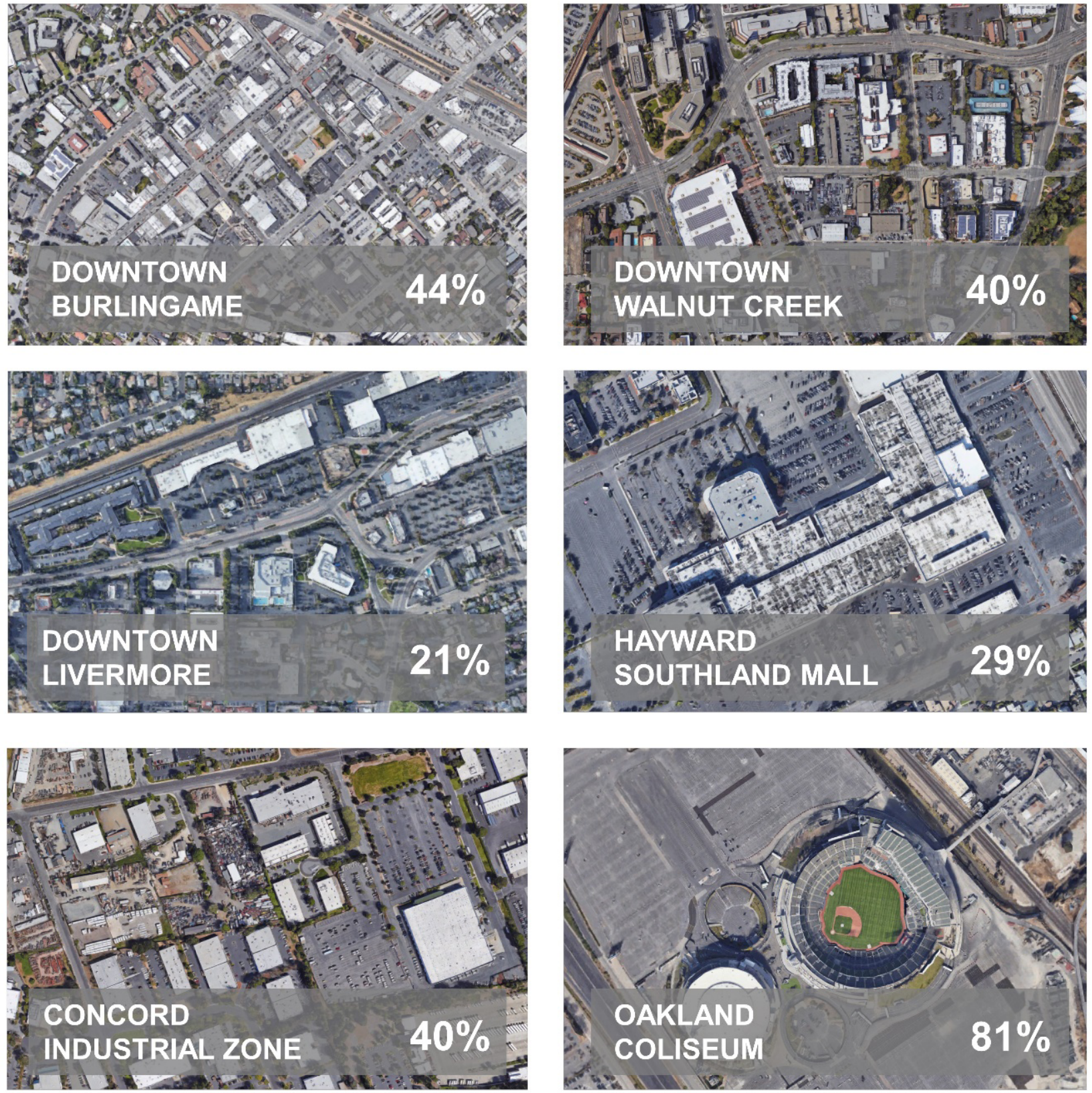

Figure 5. Urban Form Types with Large Shares of Land Devoted to Parking.

Occasionally, parking has a significant impact on land use. These six examples display some of the variation in parking implementation in the Bay Area.

Comparing the Bay Area against Los Angeles and Phoenix provides helpful insights into the commitment, extent, and utilization of parking. In general, the Bay Area outperforms its Southwest counterparts in gross parking utilization metrics. Chester (2015) and Hoehne (2019) provide commensurate findings for Los Angeles County and the Phoenix metro region respectively, developed with the same methodological approach to the work here. Comparing key metrics allows for city-to-city comparisons. Prior to comparison, it's important to note that while the Bay Area and Phoenix metro results encompass the entire urban area, the Los Angeles County results do not. Los Angeles County is the urban center of the much larger Los Angeles metro region, but no region wide estimate has been 
developed. Further, the Bay Area includes unincorporated areas, including natural and agricultural lands. The Bay Area with a population of 7.7 million people (Census Bureau, 2019) has less parking (1.9 spaces) per person than the Phoenix metro region (4.0 million people and 2.7 spaces per person) but about the same as Los Angeles County (9.8 million people and 1.9 spaces per person). Los Angeles County's comparable share can be attributed to its bounded geography and parking supply usage distributed to a massive population of travelers, as it encompasses several major commuting centers. The Bay Area has 2.4 spaces per car, well-below Phoenix metro (4.3) and Los Angeles County (3.3). It also outperforms on spaces per job at 2.7 (with Phoenix metro at 6.6 and Los Angeles County at 4.7) (Chester 2015, Hoehne 2019). The portion of paved surfaces in the Bay Area is significantly smaller than Phoenix Metro and Los Angeles County. Approximately $20 \%$ of the incorporated area of the Bay Area is paved with parking $(7.9 \%)$ and roadways $(12.4 \%)$. This is roughly one-half that of the $36 \%$ paved Phoenix metro (10\% parking, $26 \%$ roadways) and the $41 \%$ paved Los Angeles County (14\% parking, $27 \%$ roadways) (Chester et al., 2015; Hoehne et al., 2019)research strategy, and findings: Many cities have adopted minimum parking requirements, but there is relatively poor information about how parking infrastructure has grown. We estimate how parking has grown in Los Angeles County (CA. In general, the Bay Area appears to have a parking supply that is better utilized than Phoenix metro and Los Angeles County, which is unsurprising given that the region experienced significant growth pre-automobile. 


\section{CONCLUSION}

The Bay Area parking supply inventory represents a valuable product from which to assess the impacts of policy and urban form changes. The inventory is well-positioned to support assessments of changes to parking supply including pricing and redevelopment. The results are perhaps most useful when analyzed at the neighborhood level. The spatially explicit results can be used to guide policy and decision-makers towards particular neighborhoods where parking challenges are more prevalent and can provide a benchmark for analyzing policy and redevelopment. Future work could focus on the linkages between parking supply and demand. This could include how parking supply has changed over time and how auto ownership and registrations have followed (Chester et al., 2015; Hoehne et al., 2019)research strategy, and findings: Many cities have adopted minimum parking requirements, but there is relatively poor information about how parking infrastructure has grown. We estimate how parking has grown in Los Angeles County (CA or influences vehicle travel, impacts the environment and contributes to heat island (Hoehne et al., 2020), and where particular policies (such as allowances for converting home garages to secondary dwelling units to increasing housing supply) are more likely to be impactful. Related, the results provide critical information for rethinking housing policies writ large, for example where off-street parking requirements constrain the number of units that can be built. Furthermore, transit-oriented development projects should consider the results as an overabundance of parking may work against transit adoption but be an opportunity for higher density construction. By establishing spatially explicit parking supply baselines for the Bay Area, new insights will hopefully be created towards rethinking urban space for future challenges. 


\section{ENDNOTES}

1. https://www.spur.org/publications/urbanist-article/2019-03-01/bay-area-place-types 


\section{REFERENCES}

Akbari, H., Rose, L. S., \& Taha, H. (2003). Analyzing the land cover of an urban environment using high-resolution orthophotos. Landscape and Urban Planning, 63(1), 1-14. https://doi.org/10.1016/S0169-2046(02)00165-2

Angst, M. (2021, April 23). 'Tremendously overparked' San Jose looks to shed decadesold parking requirements. The New York Times. https://www.mercurynews. com/2021/04/23/san-jose-the-most-overparked-major-california-city-could-sheddecades-old-parking-requirements/

Beroldo, S. (1990). Casual Carpooling in the San Francisco Bay Area. Transportation Quarterly. https://babel.hathitrust.org/cgi/pt?id=uc1.c104685899\&view=1up\&seq= 143\&skin=2021

Boating San Francisco. (2020). Marinas. https://boatingsf.com/listings/marinas/

Brown, A. (2019). Redefining Car Access. Journal of the American Planning Association, 85(2), 83-95. https://doi.org/10.1080/01944363.2019.1603761

California DMV. (2019). Department of Motor Vehicles Estimated Vehicles Registered by County for the Period of January 1 Through.

Census Bureau. (2010). San Francisco Bay Area. Bay Area Census. http://www. bayareacensus.ca.gov/bayarea.htm

Census Bureau. (2019). Census - Table Results. US Census Bureau. https://data. census.gov/cedsci/table?t=Populations and People\&g=0400000US06.150000\&y= 2019\&tid=ACSDT5Y2019.B01003

Census Bureau. (2021). Metropolitan and Micropolitan. Census Bureau. https://www. census.gov/programs-surveys/metro-micro.html

Cervero, R. (1993). Ridership Impacts of Transit-Focused Development in California. In University of California . https://escholarship.org/uc/item/8sr9d86r

Chandler, K. (2008). Alameda-Contra Costa Transit District (AC Transit) Fuel Cell Transit Buses: Third Evaluation Report. http://www.osti.gov/bridge

Chester, M., Fraser, A., Matute, J., Flower, C., \& Pendyala, R. (2015). Parking Infrastructure: A Constraint on or Opportunity for Urban Redevelopment? A Study of Los Angeles County Parking Supply and Growth. Journal of the American Planning Association, 81(4), 268-286. https://doi.org/10.1080/01944363.2015.109 $\underline{2879}$

Chester, M., Horvath, A., \& Madanat, S. (2010). Parking infrastructure: energy, emissions, and automobile life-cycle environmentalaccounting. Environmental 
Research Letters, 5(3), 034001. https://doi.org/10.1088/1748-9326/5/3/034001

City of Los Angeles. (2010). Mangrove Estates Site Mixed Use Development | Final Environmental Impact Report. http://clkrep.lacity.org/onlinedocs/2010/10-0875 misc 6-8-2010.pdf

Davis, A. Y., Pijanowski, B. C., Robinson, K., \& Engel, B. (2010). The environmental and economic costs of sprawling parking lots in the United States. Land Use Policy, 27(2), 255-261. https://doi.org/10.1016/J.LANDUSEPOL.2009.03.002

Fabusuyi, T., \& Hampshire, R. C. (2018). Rethinking performance based parking pricing: A case study of SFpark. Transportation Research Part A: Policy and Practice, 115, 90-101. https://doi.org/10.1016/J.TRA.2018.02.001

Gabrel, C. (2000). An Overview of Nursing Home Facilities: Data from the 1997 National Nursing Home Survey. Advance Data. https://www.cdc.gov/nchs/ pressroom/00facts/nurshome.htm

Grant, B., \& Szambelan, S. J. (2019). Bay Area Place Types . SPUR. https://www.spur. org/publications/urbanist-article/2019-03-01/bay-area-place-types

Hoehne, C. G., Chester, M. V., Fraser, A. M., \& King, D. A. (2019). Valley of the sundrenched parking space: The growth, extent, and implications of parking infrastructure in Phoenix. Cities, 89, 186-198. https://doi.org/10.1016/j. cities.2019.02.007

Hoehne, C. G., Chester, M. V., Sailor, D. J., \& King, D. A. (2020). Urban Heat Implications from Parking, Roads, and Cars: a Case Study of Metro Phoenix. Https://Doi.Org/1 0.1080/23789689.2020.1773013, 1-19. https://doi.org/10.1080/23789689.2020.17 $\underline{73013}$

McGhee, G., Sommer, L., \& Santos, M. J. (2014). Spatial History Project. Stanford University. https://web.stanford.edu/group/spatialhistory/cgi-bin/site/viz. php?id=431\&

Metropolitan Transportation Commission. (2019). San Francisco Bay Region Incorporated Cities and Towns (clipped) | San Francisco Bay Region Incorporated Cities and Towns (clipped) | Metropolitan Transportation Commission. OpenData. https://opendata.mtc.ca.gov/datasets/san-francisco-bay-region-incorporated-citiesand-towns-clipped/explore?location $=37.895951 \% 2 \mathrm{C}-122.346635 \% 2 \mathrm{C} 8.89$

Moran, M. E. (2020). What's your angle? Analyzing angled parking via satellite imagery to aid bike-network planning: Https://Doi.Org/10.1177/2399808320954205. https:// doi.org/10.1177/2399808320954205

National Research Council. (2007). National land parcel data: A vision for the future. National Land Parcel Data: A Vision for the Future, 1-158. https://doi. org/10.17226/11978 
NelsonlNygaard Consulting Associates Inc. (2016). DOWNTOWN OAKLAND PARKING MANAGEMENT REPORT FINAL.

Nolan, T., \& Reiskin, E. (2016). Delivering Progress FY 2015-2016 Annual Report.

San Jose Downtown Association. (2021). Park SJMap - Park SJ. Park SJ. https://parksj. org/parking-map/

Schwartz, M., Dorinson, D., Brisson, L., Castiglione, J., Hiatt, R., Koehler, J., Tischler, D., Uniman, D., Primus, J., Thornley, A., Wilson, H., Francisco, S., Knepper, V., Greenberg, A., Grose, T., Cempel, E., Wornum, C., Wu, D., Hansen, G., ... Whelan, N. (2016). San Francisco Parking Supply and Utilization Study FINAL REPORT. www.sfcta.org

SF Gate. (2018, December 4). Supes Vote To Eliminate Parking Requirements For Building Developers. Bay City News, Inc. https://www.sfgate.com/news/bayarea/ article/Supes-Vote-To-Eliminate-Parking-Requirements-For-13443528.php

Shaheen, S. A., Chan, N. D., \& Gaynor, T. (2016). Casual carpooling in the San Francisco Bay Area: Understanding user characteristics, behaviors, and motivations.

Transport Policy, 51, 165-173. https://doi.org/10.1016/J.TRANPOL.2016.01.003

Shoup, D. (2014). THE HIGH COST OF MINIMUM PARKING REQUIREMENTS. https:// doi.org/10.1108/S2044-994120140000005011

SJSU. (2021). Parking Services. San Jose State University. https://www.sjsu.edu/parking/ 


\section{ABOUT THE AUTHORS}

\section{MIKHAIL CHESTER, PHD}

Dr. Mikhail Chester is an Associate Professor of Civil, Environmental, and Sustainable Engineering and Director of the Metis Center for Infrastructure and Sustainable Engineering at Arizona State University. Broadly, his work addresses the challenges of positioning infrastructure for increasingly complex future environments, and the technical and governance strategies needed to engage with this complexity. Specific to urban infrastructure, he's led studies to quantify the extent and implications of metro region parking supply in Los Angeles and Phoenix, including urban heat island effects.

\section{ALYSHA HELMRICH, PHD}

Dr. Alysha Helmrich is an urban systems engineer with a B.S. and M.S. in Environmental and Ecological Engineering from Purdue University and a PhD in Civil, Environmental, and Sustainable Engineering from Arizona State University. Her research interests include urban resilience, infrastructure systems, systems-thinking, and decision-making under uncertainty.

\section{RUI LI}

Rui Li is a PhD Candidate in Civil, Environmental, and Sustainable Engineering at Arizona State University. Her research interests focus on transportation infrastructure climate vulnerability analysis. She has led research efforts to study large-scale transportation network vulnerability to climate hazards including California roadway risk to post-wildfire debris flows and heat mitigation infrastructure and travel behavior change for metro active transport across Phoenix. 


\section{MTI BOARD OF TRUSTEES}

Founder, Honorable

Norman Mineta*

Secretary (ret.),

US Department of Transportation

Chair,

Will Kempton

Retired Transportation Executive

Vice Chair,

Jeff Morales

Managing Principal

InfraStrategies, LLC

Executive Director, Karen Philbrick, PhD*

Mineta Transportation Institute San José State University

\section{Winsome Bowen}

Chief Regional Transportation

Strategy

Facebook

\section{David Castagnetti}

Co-Founder

Mehlman Castagnetti

Rosen \& Thomas

\section{Maria Cino}

Vice President

America \& U.S. Government

Relations Hewlett-Packard Enterprise

\author{
Grace Crunican** \\ Owner \\ Crunican LLC
}

\section{Donna DeMartino}

Managing Director

Los Angeles-San Diego-San Luis

Obispo Rail Corridor Agency

John Flaherty

Senior Fellow

Silicon Valley American

Leadership Form

Stephen J. Gardner *

President \& CEO

Amtrak

\section{Rose Guilbault}

Board Member

San Mateo County

Transit District (SamTrans)

\section{Kyle Holland}

Senior Director,

Special Projects, TAP Technologies,

Los Angeles County Metropolitan

Transportation Authority (LA Metro)

Ian Jefferies*

President \& CEO

Association of American Railroads
Diane Woodend Jones

Principal \& Chair of Board

Lea + Elliott, Inc.

Elissa Konove*

Acting Secretary/Undersecretary

California State Transportation

Agency (CALSTA)

\section{Therese McMillan}

Executive Director

Metropolitan Transportation

Commission (MTC)

Abbas Mohaddes

President \& COO

Econolite Group Inc.

\section{Stephen Morrissey}

Vice President - Regulatory and

Policy

United Airlines

\section{Dan Moshavi, PhD*}

Dean, Lucas College and

Graduate School of Business

San José State University

Toks Omishakin*

Director

California Department of

Transportation (Caltrans)
Takayoshi Oshima

Chairman \& CEO

Allied Telesis, Inc.

Greg Regan

President

Transportation Trades Department, AFL-CIO

Paul Skoutelas*

President \& CEO

American Public Transportation

Association (APTA)

\section{Kimberly Slaughter}

CEO

Systra USA

Beverley Swaim-Staley

President

Union Station Redevelopment

Corporation

\section{Jim Tymon*}

Executive Director

American Association of

State Highway and Transportation

Officials (AASHTO)

$*=$ Ex-Officio

** = Past Chair, Board of Trustees

\section{Directors}

\section{Karen Philbrick, PhD}

Executive Director

\section{Hilary Nixon, PhD}

Deputy Executive Director

\section{Asha Weinstein Agrawal, PhD}

\section{Education Director}

National Transportation Finance

Center Director

\section{Brian Michael Jenkins}

National Transportation Security

Center Director

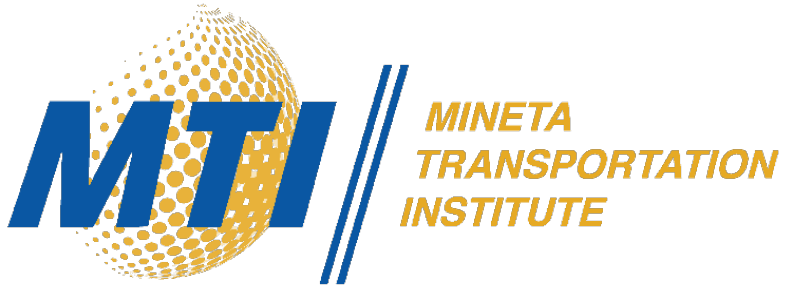

